\title{
EENIGE BLADZIJDEN UIT HET LEVEN DER COMMAN- DEURS VAN SURINAME IN DE JAREN 1680 TOT 1804
}

\author{
DOOR
}

FRED. OUDSCHANS DENTZ

De positie van commandeur van de militie is, sedert de kolonie in 1667 in Zeeuwsche handen viel, steeds belangrijk geweest. Na Crijnssens verovering op 27 Februari van genoemd jaar zien wij enkele commandeurs genoemd, als Pieter Versterre 1), Tobias Adriaenszen 2) en Everard van Hemert ${ }^{3}$ ), die bij vertrek van gouverneurs het bestuur over het gewest hebben uitgeoefend als naaste in rang, ofschoon de raden van politie meermalen bij ontstentenis van een gouverneur zich het gezag hebben aangematigd.

Wanneer wij een en ander uit het leven van opvolgende commandeurs van Suriname willen mededeelen, vangen wij de reeks aan bij den commandeur, die Cornelis van Aerssen van Sommelsdyck bij zijn aankomst in 1683 in de kolonie aantrof, nl. Laurens Verboom 4).

Deze kapitein, - als oudste kapitein was hij commandeur -

1) Pieter Versterre, opvolger van gouverneur Lichtenberg of Lichtenbergh. Zijn weduwe huwde met Herman van Hagen, in April 1689 raad van politie, in 1693 tot raad van civiele justitie benoemd.

2) Tobias Adriaenssen, kapitein van een vendel voetknechten, legt den eed als kapitein-commandeur op 22 December 1677 af. Vertrok 15 Maart 1678 uit Suriname, waar hij in 1685 terugkwam.

3) Everard van Hemert, tot commandeur in 1678 aangesteld, was kapitein van een vendel voetknechten. $Z$ ijn naam wordt het laatst in de notulen van den raad van politie in 1680 genoemd. Hij overleed in September van dat jaar.

4) Zoon van Reynbrand Verboom Laurens Rembrantsz, raad van Zierikzee, en Anna Brandyn Hubrechtsd. De weduwe Verboom huwde op 26 December 1690 met haar neef Joan Muenicx, geboren 2 Maart 1665 , en is in Suriname op 1 September 1724 overleden. Hij was ouderling, weesmeester, raadsheer in het Hof van civiele justitie, burgerkapitein, raadsheer in het Hof van politie en crimineele Justitie, provisioneel raad-fiscaal en eigenaar van de plantage Clarenbeek. Mevrouw Muenicx-Muenicx overleed op 23 Februari 1696. 
wiens naam voor het eerst op 11 September 1680 1) genoemd wordt (met Van Hemert, en na diens dood alleen, bestuurde Verboom in werkelijkheid de kolonie, toen Heinsius in 1680 overleed), was met Anna Elizabeth Muenicx 2), dochter van den raad-fiscaal $\mathrm{mr}$. Pieter Muenicx ${ }^{3}$ ), gehuwd, eigenaar van een suikerplantage aan de Commewijne 4). Van Aerssen van Sommelsdijck schatte hem zeer hoog en droeg hem dan ook ingevolge artikel 4 van zijn instructie met 7 anderen aan de directeuren der Societeit voor tot een benoeming als lid van den door hem in te stellen raad van politie en crimineele justitie. De gouverneur beschrijft 5) Verboom als een eerlijk man en een braaf soldaat, over wien de kolonie zeer tevreden was, ,en ick twyffel oock niet" - voegt hij eraantoe: ,ofte sal groote dienst door syne neerstigheydt, bequaemheydt en soldaetschap de Colonie toebrengen."

Ofschoon Verboom bij aankomst van Van Sommelsdijck het plan had de kolonie te verlaten, haalde de gouverneur hem, met moeite, over te blijven. De gouverneur bevestigde hem daarop in zijn rang, en stelde den directeuren in patria voor zijn traktement van 800 op 1200 gulden te brengen. Twee jaren later - $1685-$ vertrok Verboom naar Nederland om na een kort verblijf zijn functie in Suriname te hervatten. Zulks blijkt uit een brief van Van Sommelsdijck van 4 October 1685 aan de directeuren, waarin

1) Volgens het Naamregister der Regeering van Suriname sedert 1683, opgesteld in 1743, aanwezig in het Algemeen Rijksarchief in het archief van den Raad van politie, enz. no. 235, kwam Verboom in Suriname in 1684, hetgeen blijkbaar niet juist is.

2) Geboren in 1668 (een Vlaamsch-Zeeuwsch geslacht), overleed in Suriname op 23 Februari 1696. Zie noot 4 op de vorige bladzijde.

3) De raad-fiscaal Pieter Muenicx (niet G. Muenicx, zooals Wolbers zegt op blz. 82), in 1628 geboren, was burgemeester van Veere en werd 1 September 1683 raad-fiscaal in Suriname, waar hij 3 December 1691 overleed. Hij was met Maria Dirckens gehuwd.

4) De plantages hadden aan het einde der 17de eeuw nog geen naam. Deze komt voor onder no. 90 op de kaart van 1686, behoorende bij het hs. in de koloniale boekerij in Paramaribo aanwezig onder C 100, geheeten: Reize in de kolonie Suriname tot onderzoek der gronden aan de Commewyne, etc. van 20 Mei tot 11 Juni 1686 (door eenige Labadisten). Zie het artikel van prof. dr. L. Knappert, D.W.I.G. 8ste jaargang $(1926 / 7)$ blz. 193. „De Labadisten in Suriname”. Zie ook de kaart van J. Ottens uit de 1ste helft der 18de eeuw (1940). De plantage lag tegenover de Carrewassekreek, tusschen de plantages van Greenwood (Groenewoud) en Philebrecht.

s) Cornelis van Aerssen van Sommelsdijck, door Fred. Oudschans Dentz, blz. 60. 
hij o.m. schrijft 1): ,hopende dat ondertusschen commandeur Verboom sal zyn gearriveert, met welckers komste wy verhopen te verstaen, dat men in het Vaderlandt, soo in 't generael als particulier, beter sal zyn geinformeert van onsen handel en wandel; als mede dat Haar Hoog Mog: haar wat meer sullen gelegen laten, om haar te versien van goede, trouwe, ende waaragtige Advysgevers, sullende haar tot meerder eere ende reputatie strecken, alsmede tot nut ende interest van dese Colonie".

Verboom, een streng militair, die straffe tucht onderhield onder de ruwe soldaten, kwam droevig aan zijn einde. Bij den moordaanslag op den gouverneur op 19 Juli 1688 werd hij getroffen door een schot in den buik en levensgevaarlijk gewond. Negen dagen later gaf hij den geest. Tevoren had hij, na pardon aan de muiters te hebben verleend, op zijn sterfbed de raden van politie in overweging gegeven, de schuldigen in Nederland te doen straffen en hun den geest der wijsheid toegebeden. Ook maakte hij dienzelfden dag, den 25sten Juli, eenige beschikkingen over zijn plantage en beval hij aan, den naasten officier van rang in de militie, indien de raden hem daarvoor bekwaam oordeelden, het commando toe te vertrouwen. In een stroomenden regen werd Verboom den 28sten Juli met militaire eer ter aarde besteld.

De naaste in rang bij de militie was kapitein Abraham van Vredenburg ${ }^{2}$ ), die gedurende de muiterij der soldaten en den moordaanslag op den gouverneur en den commandeur een groote rol gespeeld heeft in de ontknooping van het drama. Hij was de zoon van Willem, raad van de stad Rotterdam en diens tweede vrouw Clara van Wouw. In 1682 was hij, evenals van Sommelsdijck, alleen in Suriname aangekomen met achterlating van zijn echtgenoote Jacoba Pieterson, dochter van Anthony, raad en rentmeester van $Z$. H. Hendrik Casimir II, graaf van Nassau, stadhouder van Friesland.

Eigenlijk had Van Vredenburg den vermoorden gouverneur moeten opvolgen, maar de raden van politie namen op aandrang van den fiscaal Gerrit Muenicx het gezag in handen, opdat Van Vredenburg daartoe niet zou kunnen overgaan. Deze liet het echter niet daarbij, maar diende 13 September een protest bij den raad in, die hem 14 September een plaats in hun college naast den president aanbood, ofschoon dit strijdig was met het octrooi. Om echter de bestaande verwarring niet meer te vergrooten, nam de waarnemende commandeur het voorstel aan, zoodat alle partijen

1) Alsvoren, blz. 154 .

2) Deze naam wordt ook met een $\mathrm{h}$ aan het einde geschreven. 
tezamen de zaken konden afhandelen, maar Van Vredenburg behield zich het recht voor de notulen te teekenen ,,ongepraejudicieerd zynen rang". De buitengewone toestand, waarin het land verkeerde, hadden de raden tot dezen buitengewonen maatregel genoopt, maar zij verklaarden plechtig, dat een dergelijke benoeming dan ook nimmer meer zou geschieden.

Aan den bewindhebbers der Compagnie schreef Van Vredenburg 1):

door het ongeval het provisioneel commando op my zynde gekomen, tot nader order van UEd. Groot Achtb., heb ik aan de Heeren van den Raad het regt daartoe volgens oude kostuijmen gerepresenteert, maar bemerkende dat onze rede by haar geen plaats vondt en geresolveerd waren alleen de meester te blyven, quocumque modo, heb ik de gemeene rust niet willen turberen, en maar aan my behouden het commando over de militaire affaires, tot verder dispositie van UEd. Groot Achtb. Ik bekenne dat die tot nog toe gecontinueerde successie in 't commando, waaraan geannexeerd was het Presidentschap in den Raad, somwylen zeer nadeelig is geweest en in het toekomende nog zoude kunnen zyn, alzoo dat meermalen zoude kunnen vallen op onwaardige of inhabile personen, als op diegenen, wiens eenige glorie is het welzyn deser colonie. Ik hope dat UEd. Groot Achtb. geen mishagen zullen vinden in myn doen; latende aan de Heeren Raden van Politie en Justitie in alles haar vrye dispositie, zal ik, onder Gods zegen, alle vlyt aanwenden om de resteerende militie, monterende omtrent tot negentig mannen, alle onze posten hierin begrepen, te brengen onder eene geregelde discipline, en niets verzuimen wat ten beste der colonie zal dienen.

Tusschen de raden van politie en den heer Van Vredenburg ontspon zich een uitgebreide briefwisseling over de bestuursaangelegenheden. De eerstgenoemden hebben den kapitein Van Vreedenburg als ,opperhoofd van de militie" aanbevolen in een brief van 29 Juli 1688. Bij de benoeming van Johan van Scharphuisen (Scherpenhuizen, heemraad van Thorarica en eigenaar van plantage Waterland) op 20 December 1688, waarvan de directeuren op 3 Januari 1689 aan den raad van politie kennis gaven, schreven zij 2):

en opdat voor het toekomende in cas van afsterven van den Gouverneur aldaar onderling geene differenten mogen voorvallen, zoo zal by ons daaromtrent in tyds de noodige voorziening worden gedaan gelyk wy dan middelerwylen goedgevonden hebben den Capitein Abraham van Vredenburgh, in consideratie van de goede

1) W e s t-I n d i ë dl. 1, blz. 205.

2) Alsvoren, blz. 210 . 
getuigenisse door UEd. Achtb. in zyn reguarde gedaan, en op de verdere favorabele rapporten wegens zyne dapperheid en voorzigtige conduite ons te voren $\left.{ }^{1}\right)$ gekomen, aan te stellen tot Commandeur over de militie, in plaats van wylen Laurens Verboom onder het oppergezag van den genoemden, onzen gouverneur, wien U.E.A. zal kunnen rapporteren wat rang denzelven in die qualiteit zal competeren, waaraan wy ons in deze gedragen.

Bovendien schreven de directeuren aan Van Vredenburg op 4 Januari 1689 2):

Wy lauderen ten hoogste Uwe dapperheid en goede conduite in zoo onverwachten toeval betoond, en laten ons welgevallen, dat tot voorkoming van verdere confusie en tweedragt, het gouvernement en de directie van de kolonie provisionelyk gelaten hebt aan de Politique Raden aldaar, tot dat deswege by ons nader zouden wezen gedisponeerd.... En nademaal door het afsterven van den Commandeur Verboom het commandement over de militie daar te lande is komen te vaceren, hebben wy in consideratie van den jongst gegeven preuve van uwe dapperheid en voorzigtige conduite goedgevonden UEd. aan te stellen tot commandeur over de voorzittende militie en onderhoorige forteressen op een tractement van $f 1500$ 's jaars, in de verwachting dat UEd. voor het toekomende in alle voorvallen zal gedragen, als een vaillant en kloekmoedig soldaat en commandant toestaat, waarvan de noodige instructie en commissie door den genoemden onzen Gouverneur op zyne aanlandinge zal worden overhandigd; nadat alvorens den behoorlyken eed van getrouwheid in den genoemden qualiteit door u aldaar zal wezen afgelegd, met welke charge UEd. by deze zyn feliciterende.

Bij resolutie van 31 December 1688 kenden H.H.M. aan Van Vredenburg voorrang toe vóór de raden van politie, zoodat de commandeur niet alleen in den grooten krijgsraad, maar eveneens in den Politieken raad zitting had onmiddellijk naast den gouverneur en van dezen de aangewezen opvolger was.

Wij hebben bij deze aangelegenheid eenigszins uitvoerig stilgestaan, om de belangrijkheid van deze eerste commandeursbenoeming in het licht te stellen.

$\mathrm{Na}$ vijftien jaren dienst verzocht Van Vredenburg per brief van 19 November 1697 aan de directeuren verlof naar Nederland te mogen vertrekken, waarop 14 April 1698 toestemming werd verleend.

1) Zou hier niet moeten staan: ter oore?

2) West-Indiê, blz. 210. 
Voor den commandeur was deze eed voorgeschreven: ${ }^{1}$ )

Ik beloove en sweere dat ik de Heeren Staaten Generaal der Geunieerde provintiën als mijne hoogen en wettigen souveraine overigheijd, mitsgaders de Directeuren van de Societeit deeser Lande, gelijk ook den Heer gouverneur gehouw en getrouw sal sijn, dat ik de Instructiēn en de ordres die mij albereijds als Commandant der fortresse en militie door de voorgemelde Directeurs sijn gegeeven, ende int toekomende van tijd tot tijd selfs, of door welgemelde Heer Gouverneur in haaren naame als andersints, sullen werden gegeeven, punctueelijk ende getrouwelijk naar mijn uijterste vermogen sal naarkomen, ende onderhouden, ende dat geene mijn soo te water ofte te Landen toevertrouwt is ofte sal werden toevertrouwt naar mijn uijterste vermogen beschermen ende beweeren ende voorts in al mijn doen mijn sodanig te gedragen als een goed getrouw braaf en vigilant commandant der fortressen en militie schuldig is en betaamdt te doen sonder om eeniger hande oorsaake daar van te blijven in gebreken. Soo waarlijk moet mij God almagtig helpen.

In de raadsvergadering van 2 Juli 1698 nu ontsloeg gouverneur Van der Veen Van Vredenburg van zijn eed als kapitein en commandeur en keerde deze naar patria terug. $Z$ ijn naam is nog verbonden aan de Vredenburger- of Oranjekreek en de in de Para gelegen plantage Vredenburg, waarvan de gronden hem bij warrant 2) van 4 September 1689 door gouverneur Van Scharphuisen waren toegewezen.

In de vergadering van directeuren van 3 April 1698, waarbij Van Vredenburg als commandeur en kapitein in dienst van de societeit ontslag werd verleend, werd bepaald ,,in deszelfs plaatse als commandant over de militie in Suriname aan te stellen den kapitein Francisco Antonio de Raineval 3), zonder uithoofde van dien eenig meerder tractement te mogen pretendeeren, als denzelven in qualité als kapitein competeert".

François Anthony graaf de Raineval, zooals hij elders genoemd wordt, was reeds in Suriname als luitenant aanwezig tijdens den moordaanslag op Van Sommelsdijck, en heeft, evenals Van Vredenburg, goede diensten bewezen bij het bedwingen van het oproer en de gevangenneming der muiters. Hij trad op 15 Juni 1702

1) Register van instructiën, ambtseeden, aanstellingen enz., 16911770. Alg. Rijksarchief, archief Raad van Politie en Justitie en Hof van Politie en Crimineele Justitie in Suriname, no. 230, blz. 91.

2) Warrant is het Engelsche woord voor grondbrief. Zie Oudschans Dentz, Cornelis van Aerssen van Sommelsdijck, blz. 17. Onder gouverneur Van Scharphuisen kwam er verandering in dezen tekst.

3) Hij teekent zoowel De Raineval als De Rayneval. 
in het huwelijk met Anna Elizabeth Glimmer, dochter van Cornelis, raad-fiscaal van Suriname van 1693-1703 en Anna Elisabeth Broen, dochter van den secretaris der kolonie 1). Hij was eigenaar van de plantages Ponthieu en Picardie ${ }^{2}$ ) en overleed op 29 December 1726 te Paramaribo. Onafgebroken is De Raineval 27 jaren commandeur geweest, totdat hij op 3 October 1725 uit den dienst ontslag nam; dit is de langste tijd, die een commandeur in de 17de, 18de en 19de eeuw in Suriname heeft gediend ${ }^{3}$ ).

Vijfmalen heeft hij het bestuur der kolonie waargenomen, de eerste maal $21 / 2$ jaar, na het overlijden van gouverneur De Gruyter op 27 Sept. 1707; de tweede maal, een half jaar na het overlijden op $28 \mathrm{Juli} 1715$ van gouverneur De Goyer; daarna vijf maanden na het overlijden van gouverneur De Mahony op 4 October 1717, de vierde maal een half jaar, toen gouverneur Coutier op 2 September 1721 was overleden en de vijfde maal na het overlijden op 17 September 1727 van gouverneur Temminck, toen slechts gedurende slechts 22 dagen. Hij kon dus wel op een goeden staat van dienst bogen!

$\mathrm{Na}$ zijn ontslag op 3 October 1725 nam Johannes Bley het commandement over. Deze nam ontslag op 16 September 17284). Hij overleed te Paramaribo op 8 Maart 1731.

Was het recht van opvolging bij ontstentenis van den gouverneur bij de resolutie van 31 December 1688 aan den commandeur toegekend, blijkbaar was zulks persoonlijk aan Van Vredenburg verleend, zoodat het niet als een algemeene bepaling voor de toekomst kon gelden. Dientengevolge werd op 4 October 1709 in het

1) Een dochter, Ester Cornelia de Raineval, geboren 22 Maart 1712, huwde met Jean David Cellier, raad van politie en crimineele justitie, geboren te Saint Hypolite in Languedoc. Zijn tweede huwelijk met Constantia Maria Pichot, weduwe van den fiscaal mr. W. G. van Meel, dat op grond van eenige verzuimde formaliteiten door gouverneur Mauricius was uitgesteld, werd clandestien door den Waalschen predikant Duvoisin voltrokken, ten gevolge waarvan een proces ontstond. Zie Recueil van egte stukken door Salomon du Plessis, bijlagen, IVde dl., blz. 72 e.v.

2) Op 1 Mei 1730 werd hem, volgens het journaal van den gouverneur, een vergunning voor zes maanden verleend voor schildpaddenvangst door zijn slaven in Schildpadbaai.

3) De Raineval was aangesteld tot commandeur volgens de Encyclopaedie van Ned. W.I., blz. 322 en volgens Hartsinck, blz. 895 op 3 November 1703. Het Naamregister vermeldt zijn aankomst op 2 Juli 1698.

4) Bley (West-Indië I, blz. 28) als commandeur aangesteld $21 \mathrm{Ja}$ nuari 1726 diende tot 16 September 1728 volgens Hartsinck; tot November volgens West-In dië dl. II, blz. 28 en tot 4 December 1730 volgens het Naamregister. 
reglement van de societeit vastgesteld, ,dat het Gouvernement ad interim zou worden waargenomen door den kommandeur en twee raden van Politie". Doch ook deze regeling bracht moeilijkheden met zich mede, toen de raden te kennen gaven, dat hun dit te lastig was. De directeuren besloten derhalve bij resolutie van 23 Februari 1733 daarin verandering te brengen en bepaalden: ,dat het Gouvernement zou worden waargenomen door den kommandeur en bij diens afsterven door den oudsten hoofdofficier van het garnizoen tot luitenant toe; bij diens overlijden zoude de raadfiscaal en daarna de wederzijdsche ontvangers moeten optreden". Voorts moest ,,aan den kommandeur gedurende het interim alle eer, eenen Gouverneur verschuldigd worden bewezen".

$\mathrm{Na}$ kapitein J. Bley zien wij als commandeur Johan François Cornelis de Vries, op 12 April 1730 aangesteld 1), tot zijn overlijden op 4 Maart 1735.

Van De Vries is weinig meer bekend, dan dat hij tweemalen het bestuur ad interim voerde met 2 raden van politie en wel na het overlijden van gouverneur C. E. H. de Cheusses op 26 Januari 1734 tot 11 December, en na het overlijden van diens broeder gouverneur J. A. H. de Cheusses op 26 Januari 1735. De Vries was gehuwd met Henrietta Sophie van Nauta, die 10 December 1745 te Paramaribo overleed.

De oudste kapitein was na het overlijden van den commandeur, wd. gouverneur De Vries, kapitein Pieter Bley, die derhalve als waarnemend bevelhebber optrad in afwachting van een uit Nederland te verwachten functionaris. Bley meende, toen 2 raden van politie na het overlijden van den waarnemend gouverneur De Vries op 4 Maart 1735 het bestuur zonder hem daarin te kennen in handen namen, daartegen te moeten protesteeren. Hij zond 10 Maart een krachtig vertoog aan de leden van het Hof, zich op de resolutie van 23 Februari 1733 beroepende, welk protest den volgenden dag werd behandeld maar afgewezen met de mededeeling, dat aan directeuren hierover zou worden geschreven. Bley heeft zich daarbij neergelegd. Zijn protest leidde echter tot de resolutie van H.H.M. van 2 Augustus 1735, de directeuren der societeit machtigende, om bij voorkomende gelegenheden de regeling der opvolging naar hun goedvinden te bepalen. Bley werd na aankomst van den nieuwen commandeur Van de Schep-

1) De Vries was tot commandeur benoemd volgens de Encyclopaedie van Nederlandsch West-Indië, blz. 323 op 12 Augustus 1730; volgens Hartsinck, blz. 895 op 12 April en volgens het Naamregister op 4 December 1730 . 
per tot sergeant-majoor der militie benoemd, als hoedanig hij in de zitting van het Hof op 1 Juni 1737 den eed aflegde. Hij overleed te Paramaribo op 4 Februari 1738.

Als bezitters van plantages komen talrijke leden der familie Bley in Suriname voor, vermaagschapt aan invloedrijke personen in de kolonie, als Godefroy, Mauricius (zoon van den gouverneur) enz. Hun naam is aan vele plantages verbonden als Bleyendaal (Pauluskreek), Bleyenhoop (Pad van Wanica), Bleyenhoop en Bleyenrust (Cottica).

De op 6 Juli 1735 in Nederland benoemde commandeur Gerard van de Schepper kwam 5 Maart 1736 1) in Suriname aan. Slechts 2 jaar, tot 11 September 1737, bekleedde hij zijn post, toen hij na het overlijden op 11 Augustus van gouverneur mr. Joan Raye, eerst provisioneel, nl. 4 November, en effectief 1 April 1738 tot gouverneur werd benoemd. Hij was de eerste, die den titel gouverneur-generaal droeg.

Van de Schepper was eveneens aan tal van families in Suriname verwant. Zijn beide dochters waren met twee broers Gerrit en Cornelis Pater gehuwd, zoons van den rijksten ingezetene der kolonie Gerrit Pater, die tal van plantages bezat (la Jalouzie, Beekhuizen, Zorg-en-Rust, enz.). De jongste dochter van Van de Schepper, met Cornelis Pater gehuwd, overleed 5 November 1743 te Paramaribo tengevolge van het toedienen van vergif in een kop koffie door een negerin. De gouverneur-generaal Van de Schepper, ontslagen op ingekomen klachten wegens misbruik van macht, vertrok 2 April 1743 met zijn echtgenoote uit Suriname op het schip Hofwijk. Zijn zoon Herman Nicolaas, die als provisioneel vaandrig met zijn vader in Suriname was meegekomen, werd later adjudant van gouverneur Raye en vendumeester, uit welke betrekkingen hij in 1743 ontslag verzocht. Hij was gehuwd met Appolonia Jacoba van der Meulen, eenige dochter van Balthazar (eigenaar van verscheidene plantages, o.a. Meulwijk) en Clasina van Egmont 2), van wie hij scheidde. Op 13 Juli 1751 verliet Herman Nicolaas van de Schepper de kolonie.

Thans zijn wij gekomen tot den opvolger van commandeur Van de Schepper, Marcelus Brouwer, 4 December 1737 aangesteld, 27 Mei 1738 aangekomen en 13 December 1742 overleden.

1) Volgens het Naamregister 8 Maart 1736.

2) Clasina van Egmont was weduwe van Erasmus Bedloo. 
Van dezen commandeur is ons weinig bekend 1), zoodat wij mogen aannemen, dat er zich geen moeilijkheden hebben voorgedaan, die des te meer onder zijn opvolgers zouden voorkomen.

De directeuren stelden 30 Mei 1742 tot commandeur aan den luitenant-kolonel der militie Philippe Chambrier, kapitein bij de Zwitsers, die slechts enkele dagen na Mauricius in Suriname aankwam op 31 October 1742 met het schip Abraham Jacobs en den 1sten November den eed als eerste raad van politie aflegde. Met dezen commandeur heeft Mauricius veel moeilijkheden gehad. De Nederlandsche taal verstond en sprak hij niet. Al zijn brieven waren in het Fransch en daarbij - volgens den gouverneur - in zeer slechts Fransch en vol fouten geschreven. Hij voerde met tal van hooggeplaatste personen, met wie hij in Nederland bekend was, briefwisseling, zooals met baron Piek van Soelen, die met een dochter van admiraal François van Aerssen, dus met een kleindochter van den vermoorden Cornelis Van Aerssen van Sommelsdijck, was gehuwd en mede-erfgenaam was van een derde van den eigendom der kolonie. Eveneens correspondeerde hij met zijn zwager François Cornelis van Aerssen, directeur van de Societeit van Suriname, in welke brieven hij Mauricius in een verkeerd daglicht stelde. De kwestie liep voornamelijk over den bouw van het fort Nieuw Amsterdam, dat aangelegd was naar de plannen van ir. P. D. Des Marets. De brieven van Chambrier aan Piek over den opbouw en onderhoud van het fort stelden de directeuren in handen van den gouverneur, die zich daarover niet malsch uitliet. Mauricius schreef daarover 4 December 1747 het volgende oordeel aan de directeuren: ,Maar pour la rareté du fait, provoceer ik deesen goeden Heer om die plans, zoo hy durft, aan kundigen te vertoonen, en men zal dan vinden, dat het plans geweest zijn als dat van een Harlequyn, om de Haarlemmermeer droog te Kooken: 't is geen kunst magnifique teekeningen te fabriceeren, zonder op 't bereik der kasse te letten". Mauricius achtte Chambrier totaal onbekwaam voor zijn ambt en toen deze Fransche commandant op 31 Mei 1743 met de rijke weduwe van

1) Ten onrechte schrijft Van Sypesteyn in zijn boek Jan Jacob Mauricius, 1858, blz. 99, dat de weduwe van commandeur Brouwer, 13 December 1742 overleden, toegetreden was tot de Cabale en ter viering van dit feit op 3 October 1750 een bal gaf in het huis hoek Gravenstraat en Gouvernementsplein. Bedoeld is de burgerkapitein E. Brouwer, raad van civiele justitie. Zie mijn artikel: De fortuinlijke loopbaan in Suriname van den Zweed C. G. Dahlberg. W.I. Gids Sept. 1941, blz. 269. Bij Wolbers is het goed vermeld op blz. 215. 
den raad van civiele justitie Pierre Dupeyrou in het huwelijk trad, waardoor hij eigenaar werd van hare plantages Perou, Libanon en La Nouvelle Esperance, verminderde zijn dienstijver sterk en moest de gouverneur hem herhaaldelijk tot meer plichtsbetrachting aanmanen. Chambrier deed zich als een slachtoffer van Mauricius voor, vroeg zijn ontslag op 4 Februari 1744 en werd met zijn echtgenoote een der hevigste tegenstanders van den gouverneur. Hij verliet na op 30 December van het jaar daarvoor zijn ontslag te hebben verkregen de kolonie op 14 April 1747 met het schip Concordia en heeft in Nederland Mauricius nog veel moeilijkheden berokkend.

Tot opvolger was 22 October 1746 Jean Louis Larcher van Kenenburg benoemd, sedert 1743 ritmeester der Cavalerie in het regiment Van Ginkel. Zijn acte van benoeming troffen wij aan in het Algemeen Rijksarchief ${ }^{1}$ ) en vindt hieronder een plaats.

De Directeuren van de Geoctroyeerde Societeit van Suriname in de Vereenigde Nederlanden,

Allen den geenen, die deesen jegenswoordigen zullen sien offte hooren leesen, saluut, doen te weeten, dat wy van Nooden hebbende een bequaam en ervaaren Persoon tot Commandeur over onse Militie in Suriname voorsz. omme deselve onder 't gesagh, ende authoriteit van onsen Gouverneur Mr. Joan Jacob Mauricius, Aldaar soo te waater als te Lande te commandeeren, achtervolgens het geene Hem by syne Instructie is geordonneert, ent ons daar toe weesende voorgedraagen den Persoon van Jan Louis Larcher van Kenenburg, wy ons syner bequaanheit, dapperheit, en goed beleyd volkomentlyk betrouwende den voorn. Jan Larcher van Kenenburg aangenoomen, gecommitteert ende gesteldt hebben, aanneemen en committeeren ende stellen Gem. mits deesen tot Commandeur over alle onse Militie in Suriname voorsz. omme deselve in alle krygsoeffeningen, ende actien op alle togten, wagten, besettingen ende Exploicten ten meesten dienste van de Societeit, ende hoogste affbreeck van derselver vyanden te bestieren, geleiden ende in de voorsz. qualiteit te commandeeren alle saacken Exploicten en Expeditien, die Gem. by onsen voorn. Gouverneur gelast sullen werden met de meeste voorsigtigheyt, en manhafftigheit getrouwelyck uyttevoeren, deselve Militaire Troupen in goede ordre, discipline en eenigheit te helpen houden, alle seditie, oproer en Muyterye, die hy verneemen mogte onsen voorn. Gouverneur aan te geeven en helpen weeren, ende voorts alles te

1) Verslagen van 's Rijks oude archieven, tweede serie, XII, aanwinsten der 1ste afdeeling, 1939/1940. De naam wordt op verschillende wijzen geschreven, zoowel Kenenburg, Keenenburg, Larcher en L'Archer. 
doen ende gem. in allen soo vroom en getrouwelyk te quyten als een goed en getrouw Commandeur schuldig is \& behoort te doen, ordonneeren, lasten en beveelen daaromme allen een jgelyck, die hetselve zoude mogen aangaan den voorn. Jan Larcher van Kenenburg in de voorz. synde functie als Commandeur te erkennen, respecteeren, ende gehoorsamen, aangesien wy sulx ten dienste van de Societeit bevonden hebben Also te behooren.

Aldus gedaan, Binnen Amsterdam den 22 October 1746.

W. van de POLL. vt

Ter ordonnantie van opgemelte Heeren Directeuren

J. van H. van MeEL.

Op Huyden den 7 September 1746 heeft Joan Larcher van Keneburg aan handen van den Heeren Praesideerende ter vergaderinge van de Societeit van Suriname als Commandeur gepresteert den Eedt daartoe staande.

My present.

J. VAN H. VAN MEel.

Hij vertrok van Texel en kwam 29 December 1746 met het schip Beekvliet in Suriname aan. Reeds binnen twee jaren overleed hij te Paramaribo aan de tering. Ook van dezen commandeur heeft Mauricius weinig genoegen beleefd. Veelal ziekelijk, beweerde hij zelfs om gezondheidsredenen niet op het nieuwe fort (Nieuw Amsterdam) te kunnen overnachten.

L'Archer was gehuwd met Louisa Magdalena de Rivecour, die haar echtgenoot bewogen had zich in de rij der tegenstanders van den gouverneur te scharen; hij hoopte bij een eventueele terugroeping van Mauricius tot gouverneur te worden benoemd, waarop natuurlijk niet de minste kans was. Zijn zwakke gezondheidstoestand bleek al vrij spoedig, want na een half jaar moest hij voor de geneeskundige commissie verschijnen, die op 14 Juli het volgende verklaarde ${ }^{1}$ ):

Attestatie der Doctoren Aharon Ledesma, N. Herbert de Singen, Franc. Tiberius Bouvoust, en den Chirurgyn Major Fred. Bekker, 12 July 1747.

Wy ondergeteekenden Doctoren en Practisyns in de Medicynen, beneevens den Chirurgyn Major van het Ed. Societeits Hospitaal in Suriname, certificeeren en getuigen mits deesen, dat naar genomen rype en naukeurige overlegging en consultatie aangaande de ziekte van den Wel Edelen Achtbaren Heer Jan Louis L'Archer van Keenenburg, Eerste Raad, en Commandeur over de Fortressen, en Luitenant Colonel over de Militie deezer Colonie, \& \& dewelke wy bevonden hebben te bestaan in een drooge hoest,

1) Recueil van egte stukken door Salomon du Plessis, dl. II, blz. 540, idem dl. III, Stukken en Munimenten, blz. 16. 


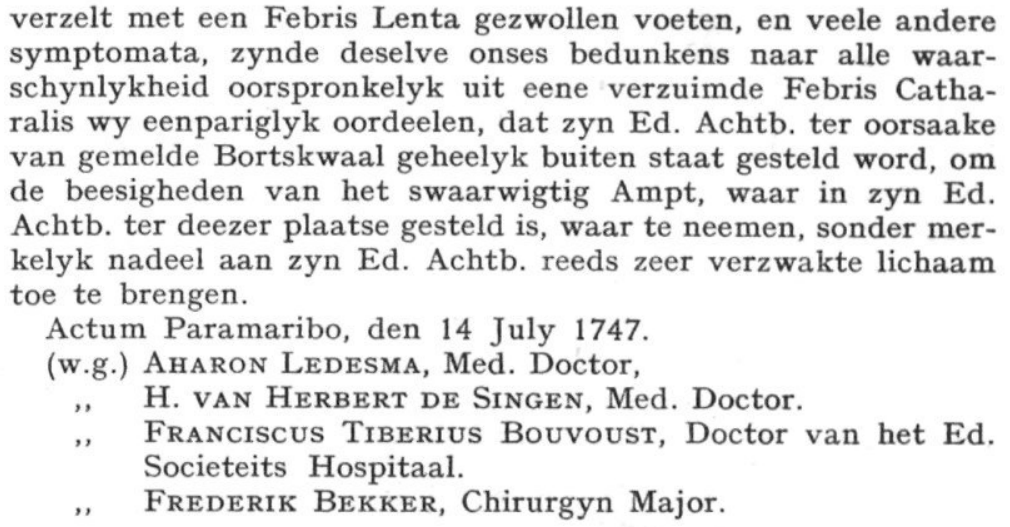

Lang heeft L'Archer het dan ook niet meer gemaakt. Reeds den 10den Mei 1748 kwam hij te overlijden. Zijn weduwe diende aan H.H.M. een klacht tegen gouverneur Mauricius in, welke 4 Augustus 1749 in hun vergadering ter tafel kwam. De klachten van de „Douarière” Larcher van Keenenburg handelden over de onvriendelijke ontvangst bij hun aankomst in de kolonie, terwijl zij n.b. door den adjudant van den gouverneur Lefebure en door de officieren W. M. van Hanekroth, De Boisguyon, A. C. Kulenkamp, E. J. Hentschel en J. F. Meyer verwelkomd waren en de nieuwe commandeur naar het gouvernementshuis werd geleid, waar hij den maaltijd gebruikte, terwijl het echtpaar met hun beide blanke bedienden 7 weken lang bij den adjudant Lefebure hebben gelogeerd en iederen dag in de koets, welke gouverneur Mauricius daarvoor zond, uit rijden gingen. De weduwe klaagde over mishandeling van haar man, wiens dood veroorzaakt werd door verdriet van de ondervonden hoon en smaad.

Mauricius heeft op die klachten 30 November 1748 geantwoord.

Zooals gewoonlijk in Suriname placht te geschieden ging de weduwe al spoedig een tweede huwelijk aan en wel met Tobias Feldner, eigenaar van de plantages Louissenburg en Killenstein Nova aan de Commewijne, een groat tegenstander van den gouverneur.

Toen de gouverneur Larcher had opgedragen met 2 raden van politie den kapitein Van Geel van 's lands oorlogschip „,Leyerdorp" bij aankomst 12 November 1747 te verwelkomen ${ }^{1}$ ), wei-

1) Volgens de resolutie van H.H.M. van 15 September 1740 was het gebruikelijk, dat de gouverneur bij aankomst van een oorlogschip, 4 gecommitteerden, waaronder de 2 de persoon in de kolonie naar boord zond om den kapitein van het schip te verwelkomen. Zulks geschiedde op Curaçao en hetzelfde gold voor Suriname. 
gerde L'Archer, zeggende ,,dat wil ik niet doen, ik ben hier Commandeur en Lieutenant Colonel en mijn caracter is hooger als dat van een Capitein van een Oorlogschip, ik weet niet van wat $\mathrm{Ca}$ racter de tweede persoon op Curaçao is, of men moet mij eerst toonen wat Caracter een Capt. ter Zee heeft en wanneer den Heer Gouverneur vermeend reden te hebben, kan hij over mijn klaagen". De gouverneur gaf Larcher daarop huisarrest op 16 November en stelde het Hof van politie daarvan in kennis. Tevens bracht hij de zaak voor den krijgsraad.

Zoo waren er meer punten van wrijving tusschen de beide hooggeplaatsten. Mauricius kon wel schrijven dat ,hij plomptelijk 't masker aflegt en geen schaduw van respect meer observeerd".

In de aanspraak welke Mauricius persoonlijk den 1sten September in de vergadering van de societeit over deze tegen hem uitgebrachte klachten hield, welke aanspraak de secretaris Van Meel, op verzoek der directeuren, op schrift stelde 1), komt o.a. deze zin voor :

Na desselfs vertrek [van Chambrier] heb ik een Commandeur gehad, die in 't begin my embarasseerde met zyne al te groote heftigheid in myn voordeel; doch (gelyk vuurtjes van stroo haast in rook verdwijnen) ook zeer haast zig in 't concept liet brengen, dat hy om zyn eigen interest my moest helpen trappen, en dat men werken zou om hem in myn plaats te brengen. 't Is UEd. Groot Agtb. bekend, hoe plomp hy my sedert gecontramineert heeft, en met wat godlooze ondankbaarheid hy en zyn Vrouw de ongemeene beleefdheden, die ik haar beweezen had, beantwoord hebben; en 't is UEd. Groot Agtb. buiten dien bekend, dat hy met de teering in 't Land gekomen zynde, gants buiten staat is geweest om, al had hy gewilt, my van eenige dienst te weezen.

Wij willen den korten, maar veelbewogen levensloop in Suriname van L'Archer besluiten met aan te halen hetgeen Mauricius nog over hem aan de H.H.M. schreef op 15 September 1749 in zijn Particuliere Remarques ${ }^{2}$ ), luidende:

De weduwe van wylen den Heer van Keenenburg zal mogelyk thans ook in den Hage, de dood haars Mans op myn rekening zetten. Egter weet al de waereld, dat die Heer, eer hy uit Texel ging, de dood reeds op de lippen had, en ik hem hier als een Broeder met allerlei beleefdheden overladen heb. In den beginne beantwoordde hy zulks met veel hartelykheid, en was tegens de Muiters heviger dan ik garen zag. Doch zoo ras men hem deed

1) Recueil dl. IV, blz. 436/7, no. 107.

2) Recueil dl. III, Stukken en Munimenten, blz. 26, no. 3 . 


\begin{abstract}
verstaan, dat de Cabale in den Hage werkte om my te doen opontbieden, en hem als eerste Commissaris in myn plaats, en zelfs tot Inquisiteur op myn gedrag, te verheffen, begreep die Heer aanstonds dat zyn intrest was mede een hand te leenen om my te helpen storten, en zyn grootheid te bouwen op myn ondergang. Hier op tourneerde hy de Casaque, zoo als men zegt, plat en plomp en alle insubordinatie breekende, lagte hy met myn orders en zelfs met de orders, proflueerende uit Resolutien van Uw Hoog Mogende. Nogtans weet de gansche Colonie, met wat zagtheid ik dit alles, uit consideratie voor zyn ziekte, behandeld heb, my contenteerende, dat hem alleen ter voldoening van 't exterieure PoInt D'Honneur van den dienst, door den Krygsraad arrest wierd geordonneert, doch zoo ras dit geschied was, heb ik hem volkomen vryheid gegeeven om te mogen uit en zelfs van 't Fort gaan, waar van hy ook dagelyks gejouisseert heeft.
\end{abstract}

Het was voor gouverneur Mauricius een opluchting, dat na de beide commandeurs Chambrier en Larcher een functionaris in de kolonie kwam, die in den tijd van zijn verblijf als commandeur getoond heeft een steunpilaar voor hem te zijn tijdens zijn gouverneurschap en daarna als gouverneur blijken heeft gegeven van degelijkheid, nl. Wigbold Crommelin.

Wigbold Crommelin was 13 September 1712 te Haarlem geboren uit een Hugenotengeslacht. Zijn vader was luitenant-generaal en commandeur. Zijn moeder heette Catharina Elisabeth Slicher. Toen hij 9 October 1748 tot commandeur in Suriname werd benoemd, was hij kapitein in het regiment van den luitenant-generaal van Leijden. Te 's-Gravenhage was hij op 21 Januari 1738 gehuwd met Johanna Barta Orrock 1), dochter van generaal Jeremias en Margaretha van Heurn, die in 1773 overleed. De directeuren schreven op 9 November 1748 aan de Raden van Politie 2):

Edel Achtbare Heeren!

Met het schip Daniel Benedictus gaat met zyne famille over de Heer Wigbold Crommelin, welke wy, in plaats van den overledenen Heer Jan Louis l'Archer tot Commandeur en LuitenantColonel over onze forteresse en militie hebben aangesteld. H.H.M. de Heeren Staaten-Generaal hebbende goedheid gehad hem ook te munieeren met haar resolutie nopens een sessie in den politiquen raad en groote krygsraad alomme voor de raden van politie. Wy wenschen in syn persoon te hebben aangetroffen alle qualiteyten, die in een braaff Commandeur en eerste raad werden vereist ten

1) Een afstammelinge van een Schotsch geslacht in Nederland. Ned. Leeuw, jrg. LV, 300 en 1938, no. 6.

2) West-In diē, I, blz. 37 . 
eynde waardiglyk de post, waarmede wy hem hebben bekleed waar te nemen; en gelyk wy niet twyfelden off hy sal van syn kant alles contribueeren wat tot een volmaakte overeenstemming in den Raad ten beste van de Colonie ende goede ingezetenen van dien noodig is, soo verwagten wy ook dat UEd. Achtb. van haar kant gaarne daartoe sullen meede wercken.

Het was jammer, dat Crommelin eerst in de kolonie aankwam, toen de tweedracht tusschen gouverneur en de Cabale reeds in zulk een stadium verkeerde, dat van verzoening geen sprake meer kon zijn; de vijandelijkheden waren openlijk uitgebroken. Met raad en daad stond hij op loyale wijze Mauricius ter zijde en deze getuigt van hem: „,De Heer Crommelin, van wien anders alle reden heb om content te weezen, en wiens ijver en gedienstigheid ik met reden prijzen moet, is te laat gekomen om mij veel te kunnen helpen, dewijl bij zijn aankomst alles reeds in de war was."

Crommelins tractement bedroeg $f 4320$ 's jaars benevens 4 rantsoenen, ieder op $f 100$ 's jaars geschat. Als persoonlijke toelage ontving hij in $1754 f 1600$ per jaar daarboven als belooning voor zijn gedrag.

Over de huisvesting van den Commandeur lezen wij in het hs. van 1770 van gouverneur Jan Nepveu, Beschrijvinge van de Volk-Plantinge Suriname 1) op blz. 60: ,Myn is niet bekend, dat de Commandant Oud-tyds een expres daartoe geschikt huys heeft gehad, maar wel dat hem zeeker huys-huur is goed gedaan, dog Ao 1754 de Huysinge van de West Ind. Comp, naast 't Gouvernement daar haar eerste Commies in logeerde, toen zij de slaavenhandel aldaar voerde, verkogt zynde, heeft de Societeit hetzelve gekogt tot een woning voor den Heer Commandeur die daar ook 't gebruik van heeft"'.

Ofschoon het de bedoeling in Nederland was geweest Crommelin t.z.t. het bestuur over de kolonie op te dragen, kwamen er na het bezoek van drie commissarissen, die een onderzoek over de klachten tegen gouverneur Mauricius instelden, groote moeilijkheden, toen generaal baron Von Spörcke 2), die het bestuur had overgenomen, overleden was en kolonel Otto Christiaan baron

1) Dit hs. is in mijn bezit.

2) Hendrik Ernst baron Von Spörcke, Heer van Netzendorp, Zischendorp en Wendewisch, Erf- en Leenheer van Langelingen en Delitz, Generaal-majoor der Infanterie, kolonel over een regiment voetknechten. Overleden te Paramaribo 7 September 1752. 
Van Verschuer 1), de bevelhebber der troepen zich onwettig het bestuur had aangematigd. Wij stappen over de bijzonderheden daaromtrent heen en vermelden alleen, dat Crommelin in het gelijk gesteld werd en 2 Februari 1753 het bestuur overnam, en behield tot 22 October 1754, toen hij het aan den nieuwe benoemden gouverneur Van der Meer overgaf. Hij vroeg en verkreeg daarna verlof om naar Nederland te vertrekken. Den 20sten Maart 1756 verliet hij Suriname met het schip Geertruyda, en kwam in December van dat jaar terug. Onze commandeur werd 21 Januari 1757 ad interim en 26 September d.a.v. effectief gouverneur, welke post hij tot 22 November 1768 heeft bekleed om nogmaals met verlof te vertrekken. Het jaar na dien vroeg en verkreeg hij 27 October 1769 eervol ontslag met een pensioen van $f 1500$.

Crommelin was eigenaar van plantage Rust en Werk in de Commewyne, in het Negerengelsch Granmangron geheeten (gouverneursgrond). Daar werden zijn beide dochters begraven, Johanna Catharina, met kapitein Godfried van Borries gehuwd (overleden 8 Maart 1768), en de oudste dochter Catharina Elisabeth (overleden 29 Januari 1752).

Ook ligt op die plantage de broeder van zijn vrouw begraven, Andries Orrock, keurmeester der suiker, die 29 Juli 1768 overleed. Op een groot houten wapenbord, dat vele jaren op die plantage gehangen heeft, was het wapenschild van de Crommelins gebeeldhoud en in kleuren geschilderd. Er stond aan de achterzijde het vers:

Mits men hier landwaerts rust

En egter vordert 't werk

Dat het gemeen vereyst

So noemt men 't Rust en Werk. An-1760-no.

In de plantage Berlijn van zijn schoonzoon Godlieff van Borries was hij voor $f 30.000$ betrokken, welk bedrag hij bij den verkoop op 9 April 1778 kwijt raakte. Van zijn pogingen om nog eenmaal naar Suriname terug te keeren, waarvoor hij 10 April 1779 de medewerking van zijn neven Mr. Anthony Slicher 2) en

1) Otto Christiaan baron Van Verschuer, vrijheer des Heiligen Roomschen Rijks, Erf- en gerichtsheer tot Soltz, enz., kolonel der infanterie. Overleden te Paramaribo 17 Mei 1753.

2) Mr. Anthony Slicher, burgemeester van Haarlem, raad ter admiraliteit te Amsterdam en bewindhebber der O.I. Comp.

West-Indische Gids XXIV 
Testart 1) inriep, is niets gekomen. In 1775 hertrouwde Crommelin met Sybrandina Cornelia Johanna Storm van 's Gravesande. Hij overleed in Grave 5 Maart 1789 in den ouderdom van 76 jaar.

Als commandeur was Crommelin opgevolgd door majoor Charles Egon de Langes de Beauvesen, die 4 Mei 1757 werd aangesteld en 1 April 1771 overleed Van hem is weinig bekend, alleen, dat hij eigenaar was van den houtgrond Oranje in de Para. Na hem kwam op 3 Juni 1771 de kapitein Arend de Jager als commandeur in de kolonie terug, die daar reeds, evenals de Beauvesen, bij de staatsche troepen had gediend; beiden waren in 1754 naar Nederland teruggekeerd. Ook De Jager overleed in Suriname en wel kort na zijn aankomst op 30 Januari 1772.

Bernard Texier was de daarop volgende commandeur, 6 Mei 1772 aangesteld. Op 27 Februari 1779, na het overlijden van Jan Nepveu, nam hij ad interim het bestuur als gouverneur over, om 3 Februari van het volgend jaar effectief als zoodanig te worden benoemd. Texier had zich bij den slavenopstand in Berbice in 1763 zeer gunstig onderscheiden als kapitein-commandant der Surinaamsche hulptroepen 2). Toen hij 7 Augustus 1764 tot 2de raad-fiscaal werd aangesteld, had hij gehoopt de lucratieve betrekking van 1sten raad-fiscaal te kunnen verkrijgen, maar werd hierin teleurgesteld. Zijn benoeming door directeuren tot commandeur was een schadeloosstelling, waardoor hij het tot gouverneur bracht. Hij was een wijs en voorzichtig bestuurder en overleed te Paramaribo op 23 September $\left.1783^{3}\right)$. Hij heeft de voldoening genoten Suriname voor Nederland te hebben behouden door krachtige maatregelen op het gebied der verdediging, toen de naburige koloniën Berbice, Essequebo en Demerary door de Engelschen werden veroverd. Behalve de militaire eigenschappen die Texier bezat, bevorderde hij zoo veel mogelijk cultureele zaken en steunde hij den arbeid van de zending der Moravische broeders (Herrnhutters).

1) Elbert Testart, schepen, raad en burgemeester van Haarlem, raad ter admiraliteit te Amsterdam, bewindhebber der O.I. Comp. wiens moeder, Geertruid Slicher, een zuster was van Crommelins moeder. Zijn dochter was gehuwd met graaf van Heemskerk. Zie mijn artikel: „,De familie van Heemskerk in Suriname”, D.W.I.G. jrg. 20 (1938), blz. 327 e.v.

2) In 1763 brak in Berbice een ernstige slavenopstand uit, welke een grooten omvang nam. De gouverneur Van Hogenheim vroeg militaire hulp aan den gouverneur van Suriname, die 100 soldaten stuurde onder bevel van Texier.

3) Volgens het Naamregister overleden op 25 September 1783. 
Als commandeur was Texier opgevolgd door den niet minder bekenden Jurriaan François de Friderici 1), die 17 Mei 1790 als kolonel-commandeur werd aangesteld. Hij was 7 December 1751 in de Kaapkolonie geboren als zoon van Joachim, die, in dienst van de O.I. Compagnie van de Kaap naar Suriname vertrokken, na een kort verblijf met zijn echtgenoote Geertruyd van den Heever aldaar overleed, drie minderjarige kinderen nalatende. Jurriaan François kwam bij den gouverneur-generaal Crommelin in huis. Van vaandrig klom hij op tot de hoogste militaire waardigheid. Aan het hoofd van het corps vrijnegers en zwarte jagers heeft hij de kolonie onschatbare diensten bewezen. De bij de bevolking zeer beminden commandeur nam 15 Juni 1790 bij het vertrek van gouverneur Wichers het bestuur ad interim over, dat hij niet onder dien titel aanvaardde, maar als ,Commandeur die verder door de Edele Groot Achtbare Heeren Directeuren en Regeerders der opgemelde colonie geauthoriseerd was, omme het Gouvernement, geduurende het verloff van den GouverneurGeneraal Wichers waar te nemen". Op 24 Augustus 1792 werd hij effectief in zijn ambt bevestigd en op den verjaardag van den erfprins van Oranje (den lateren koning Willem I) plechtig geinstalleerd met den rang van generaal-majoor. Hij was een groot plantagebezitter en gaf werk aan vele personen. In het Sarammacca district legde hij plantages aan (La Prevoyance en Catharina Sophie, naar zijn echtgenoote genoemd) ${ }^{2}$ ), en hij ontgon het eerst het district Nickerie. Bij de inbezitneming van de kolonie door de Engelschen op 17 Augustus 1799 werd hij door den koning van Engeland in zijn waardigheid gehandhaafd, maar 4 December 1802 geschorst, toen na den vrede van Amiens, kapitein ter zee W. O. Blois van Treslong met zijn eskâder Suriname van de Engelschen overnam. Het staatsbewind der Bataafsche republiek had zijn schorsing bij besluit van 5 Juli 1802 bevolen. Als ambteloos burger bleef De Friderici in Suriname wonen, zich wijdende aan zijn plantages, een vriend en vader der armen en hulpbehoevenden. Toen hij 11 October 1812 kwam te overlijden, liet de Engelsche gouverneur Pinson Bonham hem met alle eerbewijzen aan zijn vroegeren rang verbonden ter aarde bestellen. Het lijk was des avond op een praalbed ten toon gesteld. Van al de commandeurs is hij de eenige wiens (marmeren) grafzerk op de begraafplaats ,,de nieuwe Oranjetuin" aanwezig is met die van vele andere van zijn familieleden.

1) Zie D.W.I.G., 2de jrg., blz. 122 en 10 de jrg., blz. 214.

2) Catharina Sophia Bake. 
Verscheidene ingezetenen brachten later een aanzienlijke som bijeen waarvan een fraai gedenkteeken werd vervaardigd, dat in de Hervormde kerk werd opgericht, voorstellende een doodkist, waarbij een grenadier staat te weenen. Daarboven prijkt zijn standbeeld. Het werd helaas bij den brand van 1822 met de kerk verwoest 1 ). Als laatste commandeur in de behandelde reeks tot de tweede overgave der kolonie aan de Engelschen in 1804, maakt De Friderici, die bijna zijn geheele leven in Suriname doorbracht een goed figuur.

Negen van de 16 commandeurs vonden hun graf in Suriname.

In het Naamregister (zie noot 1, blz. 2 van dit artikel) der regeering van Suriname wordt in de lijst van commandeurs nog Blois van Treslong genoemd, die 4 December 1804 het bestuur overnam en 9 December 1803 vertrok. Onder zijn opvolger als gouverneur, Pierre Berranger, gaf de kolonel der troepen Batenburg de kolonie aan de Engelschen over.

1) Van mej. E. de Friderici te Wilp bij Deventer, de laatste afstammeling van den gouverneur, ontving ik een foto van deze graftombe, genomen naar een model in het klein, staande in een houten kistje met glas, hetwelk zij eenige jaren geleden door tusschenkomst van den consul te Lugano, baron van Wassenaar ontving, die het bij een antiquar daar ter plaatse vond. Het is een raadsel hoe het daar verzeild is geraakt. 